\title{
The Lilies of Erika (Erikine lalie)
}

Author: Vincent Šikula

First Published: 1996 in: There Is No Pub on Every Hill and New Short Stories (Nebýva na každom vŕšku hostinec a z nových poviedok).

About the Author: Vincent Šikula (1936-2001) was born in the village Dubová near Trnava in Western Slovakia. He studied at the Music Pedagogical School in Bratislava, later at the State Conservatory. For a short time, he worked at Folk Art School in Modra near his birthplace. Later he was the editor of the literary review Romboid. At the same time, he worked as a screenwriter in Slovak film production. His first books, based on natural narrative, provide an entertaining way to the authentic experiences of sensitive heroes where a strong relationship with humans, nature and lasting values of life dominate. Musical motifs are a significant component of his prose. He wrote poetry and prose, his works for children and youth are also important. Several of his works were also filmed, for instance With Rozárka, There Is No Pub on Every Hill and Holiday with Uncle Rafael.

Further Important Publications: Majstri (1976, Masters; first part of the novel trilogy Masters); Muškát (1977, Geranium, second part of the novel trilogy Masters); Vilma (1979, Vilma, third part of the novel trilogy Masters); Ornament (1983, Ornament; novel); $Z$ domu na kopci (1983, From the House on the Hill; poetry).

\section{Content and Interpretation}

The Lilies of Erika is a short story about the life of a Jewish family who stayed in a small village Dubová and who was the victim of the Holocaust. The author deals with the theme of their lives during World War II before they were transported to the concentration camp. None of them came back after the war.

The plot of the novel is situated in this village Dubová (author's birthplace) and it is a time of year 1942 (and before) when the Jews from this village were transported to Auschwitz. The main character of the story is a Jewish girl Erika. Except from her, also her family and a priest Viliam Hotka are mentioned. It was the priest who tried to save this family from deportations by accepting Christian baptism.

The author in this story appears as a narrator, as a little boy who had played with little Jewish girl Erika in his childhood. Erika loved flowers a lot, especially lilies, and even though she was a Jew, she always enjoyed the Christian feast of Corpus Christi, during which the field altars are decorated with flowers. When the persecution of Jews started, Erica begun to avoid people, a gate of her house was still locked. Until when the uniformed guys came from the district town and took the whole family to the concentration camp. Only Erika's grave is still at the cemetery in the village, despite she was not buried there. She died in Poland and she has probably no grave. And there are

Ә Open Access. (C) 2021 Monika Adamická, published by De Gruyter. (cc)BY-NC-ND This work is licensed under a Creative Commons Attribution-NonCommercial-NoDerivatives 4.0 License.

https://doi.org/10.1515/9783110671056-061 
still a lot of flowers in the village, especially lilies, which she planted there. "Till nowadays in Dubová there grows and blooms every year, grows and blooms the lilies of fourteen-year-old Erika Grossová...” (Šikula, 2006, p. 50).

The whole story is written from the point of view of a small boy who, in his naive, childish way describes the events in the village in connection with deportations of Jews to concentration camps. The author, as a little boy, did not understand what was going on around his friend, a Jewish girl. Why she did not meet him anymore, despite they had been friends before. He explained it in his childish way. "She started to avoid me. And I thought, that it is because she is more godly than me and she does not want to meet me anymore". Later he wrote: "Was she forbidden to meet me by the priest Hotka? People said that he had wanted to save her! I'm just guessing not against me" (p. 49). This motif of saving the Jews by baptism during the war can be found in Slovak literature i.e. in Dominik Tatarka's $\rightarrow$ The Clerical Republic or Rudolf Jašík's $\rightarrow$ St. Elizabeth's Square.

The short story The Lilies of Erika was published in the book The Is No Pub on Every Hill and Other Short Stories (1996) as well as in the children stories The Fairy Tales and Stories (1996), later in 2006 in the magazine Bibiana. The author tried to describe the tragedy of the Holocaust to a child reader in this naive way, in a childish point of view on the Shoah.

\section{Main Topics and Problems}

The short story The Lilies of Erika tells the real story of the Gross family (see below), mainly the story of their daughter Erika who loved flowers a lot, especially lilies. According to the life of Erika, lilies can be understood as a symbol of the purity, the purity of a small (or rather teenage) Jewish girl who was a victim of the Holocaust. Her soul and her life were clean. Her only fault was that she was born as a Jewess. Lilies are a traditional symbol in Christianity. Since the Baroque period they have been associated with the Virgin Mary. They are a symbol of purity of the Virgin Mary, and they are associated with the Annunciation of the Birth of Jesus Christ. In Vincent Šikula's books, Christian symbols often appear, including the symbol of lily, what can mean innocence, purity as well as death.

The story about Erika and her family is a true story of the family who lived in the author's native village. The father Samuel Gross, the mother Elza and their two daughters Laura and Erika were transported to the concentration camp Auschwitz in 1942. Samuel was killed in 1942 as fifty one-year-old man, Elza died probably the same year, but the year of her death was impossible to be presumed. Laura was murdered in 1942 as nineteen-year-old. Erika, according to the official documents, was killed in 1942 as thirteen-year-old. Nevertheless, according to the testimony of one of the Jew living in the barrack with her, Erika died just before the camp was liberated in 1945. In the village Dubová the memorial stones Stolpersteine, which commemorate the tragedy of Gross family, were placed in the sidewalk on the Main Street in August 2015. 
In 1996, the story was included in the book God's Lane: The Anthology of Slovak Literature about the Holocaust, edited by Milan Richter.

The child's view of the Holocaust is frequently used in literature, because children, one of the main symbols of the Holocaust and synecdoches for all the innocent victims of World War II, are often ideal narrators of these events. See Arnošt Lustig's $\rightarrow$ Diamonds of the Night, Henryk Grynberg's $\rightarrow$ The Jewish War, J. R. Pick's $\rightarrow$ Society of the Prevention of Cruelty to Animals or Wilhelm Dichter's $\rightarrow$ God's Horse, Ota Pavel's $\rightarrow$ Death of the Beautiful Deer or Michał Głowiński’s $\rightarrow$ Black Seasons.

\section{Cited Works}

Šikula, V. (1998). Erikine l’alie. In: M. Richter, ed., Božia ulička. Antológia slovenskej literatúry o holokauste. Bratislava: Vydavatel'stvo spolku slovenských spisovatelov, pp. 121-124. Šikula, V. (2006). Erikine l’alie. Bibiana, 4(3), pp. 48-50.

\section{Further References}

Barborík, V. (2014). Hladanie rozprávača. Prózy Vincenta Šikulu. Bratislava: LIC. Blahová, A. (1982). Estetické a společenské v Šikulovej próze. Romboid, 17(3), pp. 72-73. Herceg, A. (2015). Stolpersteine v Dubovej. Dubovské noviny, 12(4), p. 4. Hamada, M. (1969). Hodnoty a literatúra: Nad tvorbou Vincenta Šikulu. In: M. Hamada, Básnická transcendencia. Bratislava: Slovenský spisovatel', pp. 224-225. 